\title{
Human Resource Development Practice in Nepalese Business Organizations: A Case Study of Manufacturing Enterprises in Pokhara
}

\author{
Lal Bahadur Baniya*
}

\begin{abstract}
Today's modern management regards human resource as the precious asset of an organization. How this important asset is treated and developed in the Nepalese business organizations is the main concern of this study. The study reveals that there is a lack of systematic approach towards human resource development in Nepalese business organizations. Most of the organizations neither have a personnel manager to look after human affairs nor allocate budget in their annual program for human resource development. This is a manifestation of low priority assigned to human resource in organizations. However, it is a good indication that some of the organizations have started to provide their employee the training though they lack clear policy framework.
\end{abstract}

FOR GENERATIONS, IMPORTANCE OF human resource was overlooked in business organizations. Technological advancement, information explosion, changing mix and personal values of the workforce and increasing domestic as well as global competition have created enormous pressure on organizations to change not only what they do but how they do it as well. Consequently, the human resource management has gained increasing importance in overall management of the organization regardless of their size and nature, whether they are profit or non-profit making, public or private. Now human resource management has occupied a central position in organizational management. But still the development aspect of human resource has not received as much attention as it deserves.

Human resource development (HRD) in an organization is a planned effort to facilitate employee's learning of job-related behavior, skills, knowledge, and attitude in order to improve employee performance. It is a continuous process basically designed to enhance employee's performance and satisfaction thereby improving organizational efficiency and effectiveness. In the present context of competitive and dynamic business environment, the role of human resource in overall management of an organization has become increasingly important than ever before.

Highlighting the importance of people in organization Khera (1999) opined that today when most business houses are obsessed with Total Quality Management (TQM) in order to stay ahead of competition, very few organizations realize that their most precious assets are their employees. It is Total Quality People (TQP) that holds the key to a successful enterprise. Khera further states:

Both the American Society of Training and Development and Motorola have found that for every dollar invested by a corporation in human resource development, they received a thirty-dollar return on their investment. Training people did not cost the company much

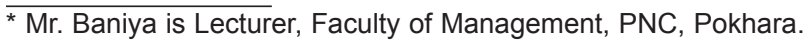




\section{Human Resource Development Practice}

but not training them cost twenty-nine dollars.

Globalization and deregulation of national economies have put forward many challenges and opportunities for the businesses across the world. To tap opportunities and to cope with challenges efficiently, skilled and competent human force has been considered as one of the most important factors. This is because all other things concerned with management of an organization are same, the only different is people. Business organizations across the world, therefore, regardless of their size and nature, have been streamlining their efforts and resources to develop skilled and competent work force providing them continuous coaching, training and other career development opportunities. They are trying to make their workforce better and different from others. More specifically, they are empowering their workforce for high performance and better results. Developing and strengthening of human capital is, therefore, essential to ensure the long-term success in today's dynamic business environment.

Nepalese business organizations are no longer untouched and uninfluenced from global trend of increasing competition, rapid change in technology and demand for competent and multi-skilled workforce. Consequently, they are experiencing a stiff domestic as well as external competition with rising demand for trained and skilled manpower.

Analyzing the Nepalese context, Agrawal (1999) observes that human resource development has remained an area of least priority in Nepalese organizations. Training is not regarded as an investment in human resources. If there is a budget cut, training becomes the first victim. Likewise, Adhikari (1992) opined that training for the workers tend to be the area of the least consideration. Some of the factory managers viewed training is not necessary on the shop-floor-level, because they learn by doing. Most of the workers are self-trained. In some organizations there are provisions for on-the-job training, but it is irregular. In fact, the process of indoctrination is very poor in manufacturing industries in Nepal.

In the above context, what practices Nepalese organizations have been pursuing to develop their human capital to keep them ready to work in changing environment and work standard is a subject of interest for investigation. An attempt, therefore, has been made here to study the human resources development practices in business organizations of Nepal with a due focus on identifying development opportunities provided for employees, measuring investment made on them, and examining consequences of providing such opportunities in an organization. In addition, concept of employee empowerment, and future challenges to Nepalese business organizations have also been assessed in the light of HRD management in Nepalese business organizations.

\section{Theoretical Framework}

Human resource management theories suggest that there is a close correlation between availability of development opportunities in an organization and performance of the people working with it. Development has to do with the increase of skill, through training, that is necessary for proper job performance (Flippo 1984). Development consists of training to increase skills and knowledge to do a particular job, and education that is concerned with increasing general knowledge, understanding, and background. There are two broad group of individuals to be trained- operatives and managers.

DeCENZO and Robbins (1996) opine that employee training has become increasingly important as job have become more sophisticated and influenced by technological changes. They classified the formal employee training methods into on-the-job training and off-the-job training. Concerning the management development training, they further state: 


\section{The Journal of Nepalese Business Studies}

Management development is more future oriented and concerned with education, than is employee training, or assisting a person to become a better performer. By education, we mean that management development activities attempt to instill sound reasoning process-to interpret knowledge-rather than teaching a specific set of motor skills. Development, therefore, focuses more on employee's personnel growth.

On-the-job management development technique includes coaching, understudy assignment, job rotation, and committee assignment; and off-the-job management development technique includes sensitivity training, transactional analysis, lecture course, simulation exercise (DeCENZO and Robbins 1996).

Bernardin and Russel (1993) opine that over the years, training has become increasingly popular as HR tool for improving employee and managerial performance in organization. It has been estimated that majority of organizations provide some type of formal training and spend millions of dollars doing so. They further write:

While top managers recognize the value of training to help their firms gain a competitive edge, so too do employees. Employees understand that opportunities for training enable them to grow and advance in their careers. Companies are offering a variety of training programs to meet their organizational need.

Referring to the future challenges of organization, Bernardin and Russel (1993) made an observation that increased competition; rapid changes in technology, the growing diversity of the workforce and occupational obsolescence are among the most important challenges for the next decade. Training is one of the most important responses to these challenges.

In addition to training, employee empowerment is equally important for better performance and better results. McDermott (ASM Group 1994) defines:

The term empowerment means, "to enable". Empowering others means creating a work environment in which people feel confident, secure, and fully capable of working and contributing at their full potential. It means removing obstacles and treating people in such a way that they feel valued and respected. When people feel empowered, they are organized, motivated, and committed to both the organization and the person doing the empowering.

It is evident from the above discussion that providing development opportunities to the employees and empowering them in the organization are the vital aspects of human resource management as they improve not only individual and organizational performance but also keep the organization ready to cope with emerging challenges.

\section{The Study Method}

At the outset, the management philosophies and their approaches towards personnel management including related past studies were reviewed. Being a descriptive study, survey research design was applied to collect required primary data. The primary data were collected from the manufacturing firms having more than 25 employees. As per the record of Gandaki Zonal Labor Office, Pokhara and office of Industrial Estate Management Ltd. Pokhara, there were altogether 23 manufacturing firms with more than 25 employees in Pokhara. Out of 23, 18 firms were found in operation. Therefore, all 18 firms were included in the study. Structured interviews were administered on the top executives-chairman, managing director and general manager-of the manufacturing firms at their office.

The filled out questionnaires were thoroughly checked, compiled and presented in appropriate forms to facilitate data analysis and interpretation. At this stage, a preliminary 60 


\section{Human Resource Development Practice}

analysis was made in order to present the findings in a discussion meeting with employees of the firms covered by the study. In order to take the opinions of employees on human resource development practices in their organizations, presidents of the enterprise level trade union were invited to a meeting where findings of the survey were presented. Comments of the employees on the findings were noted and included in the study. At the end, the employees filled out a questionnaire that demanded their opinions on different aspects of HRD in their organization. Out of 18 , employees from 13 firms participated in the discussion.

\subsection{Development Opportunities for Employees \\ 3. The Research}

Training and time adjustment for study are the two opportunities provided for employees. Table 1 indicates that majority of the firms provide on-the-job training to their employees. It is further noted that providing off-the- job training is common in all firms included in the study.

Table 1: Development Opportunities for Employees

\begin{tabular}{lcc}
\hline Development Opportunities & Number of Firms & $\%$ \\
\hline A. Training & 14 & 78 \\
a. On-the-job & 18 & 100 \\
b. Off-the-job & & \\
B. Study Facilities & 15 & 83 \\
Time Adjustment & - & - \\
Scholarship & - & - \\
Study Leave & - & - \\
C. Exposure Visit & - & \\
\hline
\end{tabular}

A good number of firms have been found to offer study facilities to the employees besides providing training. The study facility was confined to the time adjustment only for attending classes in colleges. On probing, it was reported that on-the-job training was provided for technical staff who either involved in production, machine operation or other technical field. The firms managed on-the-job training on their own resources by using senior staff members as instructors. Off-the-job training was made available to the non-technical staff working in the field of finance, marketing and management/administration. None of the firms was found extending either exposure visit, scholarship for further study or study leave for their employee.

\subsection{Areas and Subject of Training}

Table 2 depicts the areas and subjects of training offered by the business organizations. Majority of firms have found to offer training in the field of financial management followed by marketing management and production management. Human resource and office management were the least offered training by the organizations.

As is evident from the table, account keeping is the most delivered training among others as all firms surveyed reported that they did provide this training. Productivity improvement, store management, and marketing management are the other training programs provided most frequently to the employees. 
The Journal of Nepalese Business Studies

\begin{tabular}{|c|c|c|c|}
\hline Areas and Subject & Number & $\%$ & Rank \\
\hline \multicolumn{4}{|l|}{ 1. Production \& Quality Management } \\
\hline 1.1 Productivity Improvement & 13 & 72 & ii \\
\hline 1.2 Quality Management & 7 & 39 & vii \\
\hline 1.3 Production Management & 10 & 55 & iv \\
\hline Total Response & 30 & 21 & \\
\hline \multicolumn{4}{|l|}{ 2.Financial Management } \\
\hline 2.1 Account Training & 18 & 100 & $\mathrm{i}$ \\
\hline 2.2 Working Capital Management & 2 & 11 & $x$ \\
\hline 2.3 Planning \& Budgeting & 4 & 22 & ix \\
\hline 2.5 Store Management & 13 & 72 & ii \\
\hline 2.6 Financial Management & 7 & 39 & vii \\
\hline Total Response & 44 & 30 & \\
\hline \multicolumn{4}{|l|}{ 3. Marketing Management } \\
\hline 3.1 Salesmanship & 12 & 67 & iii \\
\hline 3.2 Sales Management & 9 & 50 & $v$ \\
\hline 3.3 Advertisement \& Sales Promotion & 8 & 44 & vi \\
\hline 3.4 Marketing Management & 12 & 67 & iii \\
\hline Total Response & 41 & 29 & \\
\hline \multicolumn{4}{|l|}{ 4. Human Resource Management } \\
\hline 4.1 Employee Orientation Office Management & 4 & 22 & ix \\
\hline 4.2 Communication Skills & - & - & - \\
\hline 4.3 Labor Management & 6 & 33 & vii \\
\hline 4.4 Leadership & 4 & 22 & ix \\
\hline 4.5 Motivation & 2 & 11 & $x$ \\
\hline 4.6 Human Resource Management & 2 & 11 & $x$ \\
\hline Total Response & 18 & 12 & \\
\hline \multicolumn{4}{|l|}{ 5. Office Management } \\
\hline 5.1 Filing \& Record Keeping & 6 & 33 & vii \\
\hline 5.2 Telephone Handling & 2 & 11 & $\mathrm{x}$ \\
\hline 5.3 Secretarial/Office Management & 4 & 22 & ix \\
\hline Total Response & 12 & 8 & \\
\hline Overall Response & 145 & 100 & \\
\hline
\end{tabular}

\subsection{Duration of Training and Practice of Identifying Training Need}

Out of 18 firms, two-third of firms provided short-term training of less than two weeks. The rest offered mid-term training of two to four weeks. None of the firms reported of providing training longer than four weeks duration.

The respondents were asked about the practice of identifying training need in their organization. All firms included in the study used to identify training need by doing informal inquiry with the employees. They further reported that after getting request for training from training providers like chamber of commerce and industry, management asked concerned employees, whom training is suited, to attend the course. It was stated that formal need assessment survey was non-existent in business organizations especially in manufacturing concerns of Pokhara. 
Human Resource Development Practice

\subsection{Size of Investment in HRD}

Table 3 indicates the amount of money spent by the firms on HRD in the fiscal year 2055/56. More than one-third of the firms reported that they spent less than Rs. 5,000 in a year on HRD. One-third of the firms spent the amount between Rs.5,000 to Rs.10,000. Only a few percent invest Rs. 20,000 or more in human resource in a year. The average annual investment in human resource development is Rs.8,055. It is quite low in the organizations having 64 employees on average.

Table 3: Size of Amount Invested on HRD in the year 2055/2056

\begin{tabular}{lcc}
\hline Amount (RS) & Number & $\%$ \\
\hline Less than 5,000 & 7 & 39 \\
$5,000-1,0000$ & 6 & 33 \\
$10,000-15,000$ & 2 & 11 \\
$15,000-20,000$ & 2 & 11 \\
20,000 or more & 1 & 6 \\
\hline Total & 18 & 100 \\
\hline
\end{tabular}

The respondents were also asked about budget provision for human resource development in their organization. All of the firms responded that they did not have a practice of allocating budget for human resource development. In response to a question that how did they manage fund for training, most of the firms reported that amount spent on training was not high so it was managed under the heading of miscellaneous expenses. It was interesting that all the firms did not furnish the information about their annual budget reporting that they did not have the practice of preparing it.

\subsection{Consequences of HRD Programs in Organization}

With the objective of identifying the impact on organization of providing human resource development opportunities for employees, the respondents were asked to report the consequences of the same. The respondents reported both positive and negative consequences that are as follows:

\section{Positive Consequences}

Increased productivity

Increased motivation among employers

Enhanced loyalty towards organization

Improved performance

Enhanced image of the organization

\section{Negative Consequences}

Demand for increment in salary

Demand for additional incentive and facilities

Demand for promotion

- Demonstrate over confidence in work

- Increased tendency to leave job

\subsection{Challenges of Nepalese Business}

An organization is always threatened by some challenges that may be internal and external as well. To ensure long-term success, anticipation of future challenges that likely to aggravate business is imperative. With the objective of revealing future challenges, respondents were asked to report the same they have foreseen now. Table 4 shows that low productivity, old production technology and low effort in human resource development are the most influencing internal challenges identified by majority of respondents. Likewise, weak managerial competency, increasing pressure of trade union, weak information system and poor quality are among other challenges perceived by the respondents. 
The Journal of Nepalese Business Studies

Table 4: Future Challenges of Nepalese Business Organization

\begin{tabular}{|lccc|}
\hline Perceived Future Challenges & Number & $\%$ & Rank \\
\hline A. Internal Challenges & 11 & 61 & i \\
Low Productivity & 7 & 39 & v \\
Poor Quality & 8 & 44 & iv \\
Weak Managerial Competency & 10 & 55 & ii \\
Old Production Techniques & 8 & 44 & iv \\
Increasing Pressure of Trade Union & 7 & 39 & v \\
HR Deterrent to Change & 9 & 50 & iii \\
Low Efforts at Development of HR in $\quad$ organization & 8 & 44 & iv \\
Weak Information System & & & \\
B. External Challenges & 13 & 72 & i \\
Taxation System & 9 & 50 & iv \\
High Inflation & 8 & 44 & v \\
Lack of Adequate Financing & 8 & 44 & v \\
Lack of Skilled Manpower & 12 & 67 & ii \\
Increasing Domestic and International Competition & 12 & 67 & ii \\
Inadequate \& Irregular Supply of Power, Water & 10 & 55 & iii \\
Increasing Environmental Regulation & & & \\
\hline
\end{tabular}

Concerning the external challenges, majority of respondents reported taxation system and increased domestic and international competition as their main external challenges. Inadequate and irregular supply of water and electricity, increased environmental regulation, high inflation, lack of adequate financing and lack of skilled manpower are among the upcoming challenges of their business for next five years.

\subsection{Employee Empowerment}

The significance of providing development or training opportunities in an organization largely depends on whether employees are empowered or not in that organization. For effective and efficient functioning of an organization, empowering of employees is important. Employees are to be empowered side by side providing training. To measure level of awareness of business executive on the concept of employee empowerment, a question was asked in this reference. Out of 18 firms, executives of 6 firms (33\%) are aware of the employee empowerment concept whereas executives of $12(67 \%)$ firms are unaware of this concept. Those respondents who reported to be aware of the concept stated that employee empowerment is meant the delegating authority to the employee as per their position and duty, and involving employee in decision-making.

Generalizing the attitude of employees and their relations with management, respondents expressed these opinions:

1. Employees do not understand the predicament of management. They always look on the matter from their own perspective only.

2. Employees do not come up with free hands and open heart to work together with management for the betterment of the organization.

3. Providing training for employee is not a problem for management. Management is always ready to do so. The problem is sincerity and commitment among employee. After training they will ask either for promotion, additional incentive, and facilities or leave for better job without giving prior information. 


\section{Human Resource Development Practice}

\subsection{Opinion of Employees on HRD Practices}

With a view to reveal opinions of employee on human resource development practices, employees from the firms included in this study were invited to a discussion. At the out set of the discussion, they were presented with data generated from survey with top executives. After general discussion on subject matter, respondents were asked to fill out a questionnaire that demanded information on different aspects of human resource development. Table 5 indicates the following:

1. In line with the management's opinion, employees included in this study reported that training is the only measure provided for employee to develop their knowledge and skills. Citing a nature of training, they opined a view that management provides

2. Only short-term training which does not contribute significantly for skills enhancement. Concerning the training need assessment, all employees participated in this study reported that there is no formal practice of need assessment in their organization. The usual practice is when management gets request for training from training provider like chamber of commerce and industry, they assign someone concerned with the subject to attend the course. In some case this is done without asking the concerned employee.

3. More than $50 \%$ respondents reported that management is moderately proactive in providing training for employee. Around two-third of employees reported that they are satisfied to a little extent with the training opportunity made available by the organization.

Table 5: Employees Opinion on HRD

\begin{tabular}{|c|c|c|}
\hline Questions & No. & $\%$ \\
\hline \multicolumn{3}{|l|}{$\begin{array}{l}\text { Q. What opportunities are employees getting in your } \\
\text { organization to develop job-related knowledge and skills? }\end{array}$} \\
\hline Training & 13 & 100 \\
\hline \multicolumn{3}{|l|}{ Q. Is there any practice of assessing training needs? } \\
\hline Yes & - & - \\
\hline No. & 13 & 100 \\
\hline \multicolumn{3}{|l|}{$\begin{array}{l}\text { Q. How proactive is management to provide training } \\
\text { opportunity for employees? }\end{array}$} \\
\hline Very proactive & - & - \\
\hline Moderately Proactive & 7 & 54 \\
\hline Little Proactive & 6 & 46 \\
\hline \multicolumn{3}{|l|}{$\begin{array}{l}\text { Q. To what extent are you satisfied with the training } \\
\text { opportunity made available by the organization? }\end{array}$} \\
\hline Great extent & - & - \\
\hline Some extent & 5 & 38 \\
\hline Little extent & 8 & 62 \\
\hline
\end{tabular}

Source: Opinion Survey. 


\section{The Journal of Nepalese Business Studies}

With reference to overall impression of employee about management's attitude towards providing human resource development opportunities for employees, respondents expressed the following opinions:

1. Management does not recognize employees for the work they do.

2. People in top management have low education and unaware of modern management practices. So they do not realize the value of training and employee development.

3. Some employers demonstrate a feeling - I managed to be a successful businessman without training. Why should I pay money for others?

Management is always suspicious about employees. They have a feeling that after training employees leave for better job. Employees put forth a view that this generalization should not be made for all on the pretext of a few.

\section{Major Findings of the Study}

1. Training is the only development opportunity provided for employees to develop their knowledge, skills, and abilities. Both on-the-job and off-the-job training are made available to the employees.

2. On-the-job training is offered to technical staff working in the field of production or other technical field. Off-the-job training is provided for employees working in other functional aspects of management-finance, marketing, administration, and human resource management. Accounting, productivity improvement, store management, salesmanship, and marketing management are the most common areas of training offered to the employees.

3. Majority of training provided to the employees is of short-term type of less than two weeks duration. A few firms have offered mid-term on-the-job training of 2-4 weeks. No training of more than four weeks duration was reported to be provided. Employees opined that short-term training does not keep much significance in skill enhancement.

4. Training need is identified by informal inquiry with employees. The practice of conducting formal need assessment survey is non-existent in the firms surveyed.

5. The average annual investment in HRD is Rs. 8055 that is quite low in the organizations having 64 employees on average. The average investment per employee per year is only Rs. 120 . None of the firms allocate budget for human resource development programs.

6. The positive consequences of providing development opportunities to employee are improved performance, increased productivity, enhanced loyalty towards organization, and increased motivation among employees and negative consequences are demand for increment in salary, additional incentives and facilities, promotion, and demonstration of over confidence in work, and tendency to leave job.

7. Low productivity, old production techniques, low effort at HRD, poor quality, weak managerial competency, increasing pressure of trade union, and weak information system are internal challenges to the Nepalese business. Of these, low productivity, old production techniques, and low effort at HRD are the critical one. Taxation system, inadequate and irregular supply of water and electricity, increasing domestic, international competition, high inflation, lack of adequate financing, increasing environmental regulation and lack of skilled manpower are the external challenges that would pose threats to business organizations in future. 


\section{Human Resource Development Practice}

8. Majority of business executives are unaware of the employee empowerment concept. Those who reported to be aware of too do not have a clear comprehension of the concept.

9. Management is suspicious about loyalty and sincerity of the employees. They have a deep-rooted perception that after training employees ask either for increment in salary or additional incentives and facilities or leave for better job without giving pre-notice to the management. Despite this perception, it is worth noting that firms are providing training opportunity to their staff members.

10. In view of employees, management is moderately proactive in developing human resource in their organization.

11. Employees' satisfaction with the existing training opportunity is low. Only around onethird of employees are satisfied to some extent with the opportunity made available by the organization.

12. Employees have agreed on these sayings-demand for increment in salary, demand for additional incentives and facilities, demand for promotion, demonstration of over confidence in work, and join other organization without informing existing ones-of management with some reservations. Putting forward their reservation, employees admitted that some of them occasionally exhibit such behavior after training.

\section{Implications}

1. Though the firms covered by this study, on the average, were nine years old with average number of 64 employees, it is inferred that not having a personnel manager to look after human affairs and non-allocation of budget for human resource development is a manifestation of low priority assigned to human resource in Nepalese business organizations. This is because of low level of awareness about the importance of human resource among the business executives.

2. An analysis of field and subjects of training provided for employees revealed that concentration of the Nepalese business organizations is still on traditional training like accounting, production, and salesmanship and store management. There is a complete lack of attitudinal training both at executive and employee level in the Nepalese business organizations. Therefore, it seems desirable to provide attitudinal training for both executives and employees.

3. Human resource development is a continuous process. But in Nepalese organizations, it is being treated as a sporadic event. A formal need assessment practice is almost non-existent. In order to keep pace with changing environment, an organization has to assess its training need at regular interval.

4. The cooperation and coordination between management and employee is crucial for effective and efficient functioning of an organization. Lack of confidence between them has not only seriously impeded the development of human resource in an organization but also has hindered the productivity and overall performance of the organization. For effective and efficient functioning of an organization, employees are to be empowered besides providing training and development opportunity. Since majority of Nepalese business executives are unaware of the employee empowerment concept and those who are aware too have low comprehension of the concept. This has hindered 


\section{The Journal of Nepalese Business Studies}

the development of professionalism in Nepalese business organizations. Recognizing the importance of the employees and their self-esteem, management needs to empower them.

5. It is a good signal that Nepalese business organizations are providing some forms of training to their employees despite the fact that they lack systematic approach towards human resource management and development. It is, therefore, concluded that there is an urgent need to develop systematic human resource development approach substantiated by precise policy framework and objective oriented programs in Nepalese business organizations.

\section{REFERENCES}

Adhikari, D.R. 1992. Human Resource Management for Public Enterprise: A Model for Designing Jobs in Nepalese Factories. Badan-Badan: Nomos Verlangsgesellschaft.

Agrawal, G.R. 1999. Organization and Management in Nepal. Kathmandu: M.K. Publisher and Distributor.

Asian Source Media Group. 1994. Management Essential. Vol. 3. n.p.: The ASM Group.

Bernardin, H.J., and J.E. A. Russel. 1993. Human Resource Management: An Experiential Approach. Singapore: McGraw-Hill, Inc.

DeCENZO, D.A., and S.P. Robbins. 1996. Personnel/Human Resource Management. 3rd ed. New Delhi: Prentice-Hall of India Pvt. Ltd.

Flippo, E.B. 1984. Personnel Management. 6th ed. Singapore: McGraw-Hill, Inc.

Khera, S. 1999. Just How Important Is It ? Business Age 1: 36. 